\title{
HISTORY OF ARCHEOLOGICAL DISCOVERIES RELATED TO THE FIRST URBAN CULTURE OF THE FERGANA VALLEY
}

\author{
Abdumuxtor Abduxalimovich Khakimov \\ Ph.D, Senior Lecturer Of The Department Of History Of Uzbekistan, Andijan State University \\ Ubaydullo Ibrokhimjon Ogli Komilov \\ 1st-Year Master Degree Of The Department Of History Of Uzbekistan, Andijan State University
}

\section{ABSTRACT}

The article describes the emergence and development stages of the first cities in the Fergana Valley. Also, the history of archeological discoveries related to the first urban culture of the Fergana Valley is analyzed, taking into account that the scientific study and analysis of these issues can be carried out only due to archaeological research.

KEYWORDS: - Central Asia, Fergana Valley, Southern Turkmenistan, Pamir-Alay, Pamir-Fergana, Chust culture, Khasan, Dalvarzin, Ashkaltepa, Khojambog, Eilaton, Markhamat.

\section{INTRODUCTION}

The emergence and stages of development of the first cities in the Fergana Valley, the problems of history and culture of the first cities are important issues in the history of the Motherland. Given that the scientific study and analysis of these issues can be carried out only due to archaeological research, we found it necessary to briefly dwell on the history of archaeological discoveries related to the first urban culture of the Fergana Valley.

The study of archeological monuments of the Fergana Valley, the findings of the Bronze Age of the valley was known in the late XIX - early XX centuries, but they have a common feature and do not contain information about the first cities. Special research in this area began in the 30s of the last century and 1933-1934 B.A. Latin distinguished four stages of the material culture of the Fergana Valley [1.134-141].

During archeological excavations during the construction of the Greater Fergana Canal in 1939, TG Oboldueva identified Bronze Age artifacts (fragments of pottery, stoneware, bronze knives) and compared them with objects of material culture in Turkmenistan (Nov I) [2.710]. The Pamir-Alay and Pamir-Fergana archeological expeditions led by AN Bernshtam in 1946-1948 and 1950-1952 brought a lot of clarity to the history of the first agricultural culture of the Fergana Valley and the Bronze Age steppe culture and the relations between them.

In 1950, M.E. Voronets and V.I. Sprishevsky began to study the Bronze Age monument near the city of Chust, and this monument was the 
CURRENT RESEARCH JOURNAL OF HISTORY 2(6): 72-75, June 2021

DOI: https://doi.org/10.37547/history-crjh-02-06-16

ISSN 2767-472X

(C)2021 Master Journals

\section{Crossref do) 11 Google}

Accepted 25th June, 2021 \& Published 30thJune, 2021

subject of many years of research [3.53-57]. In 1953-1961, VI Sprishevsky conducted extensive archaeological research at the Chust monument [4] and made many clarifications to the culture of the Bronze Age of the valley.

In the study of the early agricultural culture and history of the ancient cities of the Fergana Valley, Yu.A. The importance of Zadneprovsky's archeological research is incomparable. Having conducted archeological research in the Fergana Valley for many years, this scientist summarized all the archeological data in the valley, drew conclusions from the excavations of Eilaton and Dalvarzin, and divided the material culture in these areas into three major historical stages Eilaton, Marxamat, and Khasan. In 1957, the Bronze Age monuments in the valley were excavated. II-I suggested counting with the beginning of the millennium [6].

Also, Yu.A.Zadneprovsky continued his research in the Karadarya oasis in 1958-1961, identified and conducted research on the monuments of sedentary farming culture of the Late Bronze Age [7.18-20].

Since the $60 \mathrm{~s}$ of the last century Yu.A.Zadneprovsky, N.G. Gorbunova, V.I. Sprishevskiy, B.A. As a result of research by Litvinsky and other scholars, many clarifications were made on the issues of early agricultural culture and ancient cities in the Fergana Valley, and their conclusions began to be widely used to shed light on the ancient history of the peoples of Central Asia. By this time, many monuments confirming the existence of the Bronze Age culture in the Fergana Valley were introduced into science, and their findings were first compared with the findings of this period in southern Turkmenistan and Iran. At the same time, the chronological sequence of the ancient Fergana agricultural culture was determined, and for the first time in the history of Central Asian archeology, the ancient agricultural culture of Chust was singled out.

Until the 80s of the last century, VI Sprishevsky and Yu.A.Zadneprovsky researched such monuments as Chust, Dalvarzin, Ashkaltepa, Khojambog. As a result of these studies, the types of settlements and material cultural monuments belonging to the Chust culture were thoroughly analyzed and introduced into science [8]. Archaeological excavations carried out until the 1980s resulted in large-scale excavations in Dalvarzin, re-excavations in Chust, large-scale excavations in Osh and its environs [9.25-30], the chronology of Chust culture in BC. Periods with periods from the VIII-VII centuries. In addition, taking into account the local characteristics of the Chust culture, they were divided into groups. Also, based on material cultural artifacts found in the monuments of Chust culture, the peculiarities of agriculture, animal husbandry, and handicrafts of the late Bronze Age in the history of the Fergana Valley were revealed, role and place of Chust-era defense structures in Central Asia fortification.

In 1982-1983, B.Kh. Matboboev, an employee of the Institute of Archeology of the Academy of Sciences of the Republic of Uzbekistan, conducted archeological research on the monuments of Chust culture. collected new data [10.241-245].

In the late 80s of the XX century and the years of independence, the expedition of the Institute of Archeology of the Academy of Sciences led by B.Kh. Matboboev researched the monuments of Chust culture, in particular, on the statehood and early urban planning of the Fergana Valley. As a result of these studies, first of all, generalized articles on some aspects of the material culture of the Fergana Valley (Chust culture) were published, which clarified the chronology of the Dalvarzin and Chust monuments [11.46-51]. B. Matboboev made an in-depth analysis of the houses of the Bronze and Early Iron Age 
CURRENT RESEARCH JOURNAL OF HISTORY 2(6): 72-75, June 2021

DOI: https://doi.org/10.37547/history-crjh-02-06-16

ISSN 2767-472X

(C)2021 Master Journals

\section{Crossref do) 81 Google}

Accepted 25th June, 2021 \& Published 30thJune, 2021

peasants in the Fergana Valley, summarized the results of the study of the ruins of settlements identified as a result of many years of research [12.46-60]. In recent years, archeological excavations have been carried out in the eastern part of the Fergana Valley, in the Andijan region, under the leadership of B. Matboboev. It is estimated that archeological excavations have been carried out in the city for about 20 seasons so far. For example, based on the research of the same scientist, valuable materials on the history of the development of the city in ancient and medieval times, the structure of the city were published. [13].

In particular, the high skill, deeply scientific, and technical knowledge of Professor BH Matboboev allowed me to collect and classify the evidence of the history of the origin and development of the city of Andijan. The researcher was able to identify the ancient core of Andijan, which contains the remains of defensive structures, housing, and industrial complexes that lie beneath the modern city from the VI century BC to the XV-XVI centuries AD.

A brief analysis of the history of the study of the Late Bronze and Early Iron Age monuments of the Fergana Valley suggests that the archeological research carried out to date provides ample opportunities for scientific research on the first urban culture in the valley and the first statehood. However, there is no single conclusion about the historical date of the Chust culture, which is unique in Fergana. This culture was discovered by researchers in BC. As the XV-VII centuries are marked by a wide chronological circle, it is noted that the processes of urbanization in the Fergana Valley have gone through different historical paths, from 2500 to 3200 years. In our opinion, the conditions, factors, and features of the formation of the first urban planning in the valley, their comparative study with the processes of urbanization in Central Asia will undoubtedly bring serious scientific clarity to the issue in future research.

\section{ReFERENCES}

1. Латинин Б.А. Работы в районе проектируемой гидростанции на реке Нарыне в Фергане ИГАИМК. 1935. Вып 110. стр. 134-141.

2. Оболдуева. Т.Г. Отчёт о работе первого отряда археологической экспедиции на строительстве Большого Ферганского канала ТИИАН УзССР. 1951. Т. 4. - стр.710.

3. Воронец.М.Э. Археологическая исследования Института истории Академии наук Уз ССР на территории Ферганы в 1950-1951 ТМИ УзССР. Вып.2 1954.стр.-53-57.

4. Спришевский В.И. Чустское поселение (К истории Ферганы в эпоху бронзы). Автореферат, дисс.канд.ист.наук.-Т., ИИА АН Уз ССР. 1967.

5. Заднепровский.Ю.А. Древняя Фергана. Автореф. дисс.канд.ист.наук -Л. ЛОИА АН СССР, 1954.

6. Заднепровский.Ю.А. Дальверзинские селище КСИИМК, 1957, Вып 69.

7. Заднепровский. Ю.А. Основные этапы истории Карадарьинского оазиса КСИА. 1964. Вып. 98, стр 18-20.

8. Заднепровский.Ю.А. Чусткая культура Ферганы и памятники раннежелезного века Средней Азии. Автореф.докт.дисс.М.ИААН СССР, 1978.

9. 9. Заднепровский.Ю.А. Ошское поселение бронзового века Памятники Киргизии1982.Вып.5.стр. 25-30.

10. Матбабаев Б.Х. Новые исследование на Чустском поселение (Фергана) СА.1984. №4. стр, 241-245. 
CURRENT RESEARCH JOURNAL OF HISTORY 2(6): 72-75, June 2021

DOI: https://doi.org/10.37547/history-crjh-02-06-16

ISSN 2767-472X

(C)2021 Master Journals

Crossref do: 81 Google

Accepted 25th June, 2021 \& Published 30th June, 2021

11. Матбабаев Б.Х., Заднепровский Ю.А. Итоги изучения Чустского поселения в Фергане (1950-1982) ИМКУ-1984. Вып. 19, стр. 46-51.

12. Матбабаев. Б.Х. Исследования жилищ в памятниках Чустской культуры Ферганы (XII-VII вв. до н.э.) ИМКУ-Т., 2002, вып.33, стр. 46-60.

13. Матбобоев Б.X, Машрабов 3.3. Андижон тарихи (қадимги даврлардан XX аср бошларигача) "Sharq”. Тошкент 2014.

14. Khalimovich, O. N., Rasuljanovna, I. N., \& Shakarovich, G. I. (2020). The Purpose and Outcome of Diplomatic Missions in the II-I Centuries Between Central Asia And China. Journal of Critical Reviews, 7(9), 126-128.

15. Shomirzayev, M. K. (2019). THE ETHICAL CHARACTERISTICS OF TRADITIONAL EMBROIDERY OF FERGANA VALLEY PEOPLE. European Journal of Research and Reflection in Educational Sciences Vol, $7(12)$. 